\title{
Aspek Hukum Persetujuan Tindakan Medis (Inform Consent) Dalam Pelayanan Kesehatan
}

\author{
Achmad Busro \\ Fakultas Hukum, Universitas Diponegoro, Jl. Prof. Soedarto No. 1 Tembalang \\ E-mail : achmadbusyro@roketmail.com
}

\begin{abstract}
Approval of medical treatment (inform consent) in health services is a matter that must be carried out by doctors to patients in terms of legal aspects. For this reason, it is necessary to pay attention to the implementation of the medical action agreement. So to note also the obstacles and solutions to overcome the implementation of health services to patients, so that there is a legal protection for both doctors and patients.
\end{abstract}

Key Words : Inform Consent, Doctor, Patient

\begin{abstract}
Abstrak
Persetujuan tindakan medis ( inform consent ) dalam pelayanan kesehatan merupakan suatu hal yang wajib dilakukan oleh dokter terhadap pasien ditinjau dari aspek hukumnya. Untuk itu perlu diperhatikan dalam implementasinya persetujuan tindakan medis itu. Jadi untuk diperhatikan pula hambatan dan solusi mengatasi dalam pelaksanaan pelayanan kesehatan kepada pasien, sehingga terdapat adanya perlindungan hukum baik bagi dokter maupun pasien.
\end{abstract}

Kata Kunci : Inform Consent, Dokter, Pasien

\section{LATAR BELAKANG}

Tingkat keberhasilan kualitas pelayanan kesehatan dapat dipandang dari tiga subyek yakni 1) pemakai, 2) penyelenggara dan 3) penyandang dana pelayanan kesehatan. Bagi pemakai jasa kesehatan, kualitas pelayanan lebih terkait pada dimensi ketanggapan petugas memenuhi kebutuhan pasien, kelancaran komunikasi petugas dengan pasien. Bagi penyelenggara pelayanan kesehatan, kualitas pelayanan kesehatan lebih terkait pada dimensi kesesuaian pelayanan yang diselenggarakan dengan perkembangan ilmu dan teknologi mutakhir dan/atau otonomi profesi dalam penyelenggaraan pelayanan kesehatan. Sedangkan bagi penyandang dana pelayanan 
kesehatan, lebih terkait dengan dimensi efisiensi pemakaian sumber dana, kewajaran pembiayaan kesehatan, dan/atau kemampuan pelayanan kesehatan mengurangi kerugian penyandang dana pelayanan kesehatan. ${ }^{1}$

Seiring dengan berkembangnya pelayanan kesehatan dan pelayanan medik tersebut maka peranan hukum dalam pelayanan kesehatan dan pelayanan medik semakin meningkat. Menurut Pasal 52 UU No. 36 Tahun 2009 Tentang Kesehatan, yang menyatakan bahwa pelayanan kesehatan terdiri atas pelayanan kesehatan perorangan dan pelayanan kesehatan masyarakat. Pelayanan kesehatan tersebut menurut UU ini meliputi kegiatan dengan pendekatan promotif, preventif, kuratif, dan rehabilitatif.

Pelayanan kesehatan dibedakan atas dua macam yaitu 1) pelayanan kesehatan masyarakat (Public Health Service) dan 2) pelayanan kesehatan kedokteran (Medical Service), untuk pelayanan kedokteran dapat diselenggarakan sendiri dengan tujuan utamanya yaitu untuk mengobati (Kuratif) penyakit dan memulihkan (Rehabilitatif) kesehatan serta sasaran utamanya adalah perseorangan. Sedangkan pelayanan kesehatan masyarakat umumnya diselenggarakan bersama-sama dalam suatu organisasi bahkan harus mengikutsertakan potensi masyarakat dan mencegah penyakit serta sasaran utamanya adalah masyarakat secara keseluruhan. Di samping pelayanan kesehatan juga ada pelayanan medik di mana pelayanan ini mencakup semua upaya dan kegiatan berupa pencegahan (Preventif), pengobatan (Kuratif), peningkatan (Promotif), dan pemulihan (Rehabilitatif) kesehatan yang didasarkan atas hubungan individual antara para ahli di bidang kedokteran dengan individu yang membutuhkannya.

Berdasarkan hak, maka setiap pasien mempunyai hak untuk mengetahui prosedur perawatan bagaimana yang akan dialaminya, termasuk risiko yang harus ditanggungnya sebagai akibat metode perawatan tertentu. Kecuali itu pasien juga mempunyai hak untuk mengetahui apakah ada alternatif-alternatif lain, termasuk pula resikonya. Ada pula yang berpendapat bahwa pasien berhak mengetahui hal-hal yang berada di luar ruang lingkup kesehatan, namun yang berkaitan, seperti misalnya, faktor sosial. Itulah yang

Titik Triwulan Tutik dan Shita Febriana, 2010, Perlindungan Hukum Bagi Pasien, Prestasi Pustaka Publisher, Jakarta, halaman 13. 
lazim disebut "informed consent", yakni persetujuan yang diberikan setelah mendapatkan informasi selengkapnya. ${ }^{2}$

Informed consent adalah suatu persetujuan mengenai akan dilakukannya tindakan kedokteran oleh dokter terhadap pasiennya. Persetujuan ini bisa dalam bentuk lisan maupun tertulis. Pada hakikatnya informed consent adalah suatu proses komunikasi antara dokter dengan pasien mengenai kesepakatan tindakan medis yang akan dilakukan dokter terhadap pasien. Penandatanganan formulir informed consent secara tertulis hanya merupakan pengukuhan atas apa yang telah disepakati sebelumnya. Tujuan penjelasan yang lengkap adalah agar pasien menentukan sendiri keputusannya sesuai dengan pilihan dia sendiri (informed decision). Oleh karena itu, pasien juga berhak untuk menolak tindakan medis yang dianjurkan. Pasien juga berhak untuk meminta pendapat dokter lain (second opinion), dan dokter yang merawatnya.

Kewajiban memberikan penjelasan atau informasi kepada pasien adalah penanggung jawab perawatan terhadap pasien tersebut, misalnya seorang dokter. Dalam keadaan-keadaan tertentu dokter tersebut dapat mendelegasikan wewenangnya kepada tenaga kesehatan lain, akan tetapi tanggung jawab hukum tetap ada padanya. Secara yuridis, seorang perawat sebenarnya tidak berwenang melaksanakan proses "informed consent". Hal ini menjadi tugas dokter, dan kalau ada pendelegasian wewenang, maka dokter harus yakin benar bahwa perawat yang diberi tugas benar-benar menguasai masalah dan mampu memberikan penjelasan yang dipahami oleh pasien. Oleh karena itu dari sudut hukum tanggung jawab mengenai "informed consent" tetap ada pada dokter. $^{3}$

\section{Permasalahan}

1. Bagaimana implementasi persetujuan tindakan medis ( informed consent) dalam pelayanan kesehatan?

2. Bagaimana pelaksanaan persetujuan tindakan medis (informed consent) dalam pelayanan kesehatan?

2 Soerjono Soekanto, 1989, Aspek Hukum Kesehatan (Suatu Kumpulan Catatan), Penerbit IndHill-Co, Jakarta, halaman 68.

3 Ibid, halaman 68-69. 
3. Bagaimanakah hambatan-hambatan dan solusi untuk mengatasinya dalam pelaksanaan persetujuan tindakan medis (informed consent) dalam pelayanan kesehatan?

\section{PEMBAHASAN}

\section{Perjanjian Pada Umumnya}

\section{Pengertian Perjanjian}

a) Menurut R. Subekti, Perjanjian adalah suatu peristiwa dimana seseorang berjanji kepada seseorang yang lain atau dimana dua orang saling berjanji untuk melaksanakan suatu hal. ${ }^{4}$

b) Menurut Abdulkadir Muhammad, Perikatan adalah suatu hubungan hukum antara dua orang atau dua pihak berdasarkan mana pihak yang satu berhak menuntut suatu hal dari pihak yang lain dan pihak yang lainnya berkewajiban untuk memenuhi tuntutan tersebut. ${ }^{5}$

c) Dhani Wiradharma, mengartikan bahwa Persetujuan adalah sama dengan perjanjian. $^{6}$

d) Menurut Pasal 1313 KUHPerdata, Suatu persetujuan adalah suatu perbuatan dengan mana satu orang atau lebih mengikatkan dirinya terhadap satu orang lain atau lebih.

\section{Subyek dan Obyek Perjanjian}

Subyek dalam perjanjian adalah pihak-pihak yang terdapat dalam perjanjian. Ada dua macam subyek, yakni seseorang manusia atau suatu badan hukum yang mendapat beban kewajiban atau mendapat hak atas pelaksanaan kewajiban itu. Subyek yang berupa seorang manusia haruslah memenuhi syarat sah untuk melakukan tindakan hukum yaitu sudah dewasa dan tidak berada dibawah pengampuan.

Sedangkan obyek dalam perjanjian adalah berupa prestasi, yang berujud memberi sesuatu, berbuat sesuatu, dan tidak berbuat sesuatu. Perikatan untuk memberi sesuatu ialah kewajiban seseorang untuk memberi atau menyerahkan sesuatu, baik secara yuridis maupun penyerahan secara nyata. Perikatan untuk berbuat sesuatu yaitu prestasi

\footnotetext{
R. Subekti, Hukum Perjanjian, Intermasa, Jakarta,1992, hal 1.

Abdulkadir Muhammad, Hukum Perikatan, Alumni, Bandung, 1982, hal. 76.

J. Guwandi, Tanya Jawab Persetujuan Tindakan Medik (Informed Consent), Fakultas Kedokteran UI, Jakarta, 1994, hal.49.
} 
dapat berujud berbuat sesuatu atau melakukan perbuatan tertentu yang positif. Sedangkan perikatan untuk tidak berbuat sesuatu yaitu untuk tidak melakukan perbuatan tertentu yang telah dijanjikan.

Dalam hal ini terdapat tiga macam obyek, yakni :

a) Barang-barang yang dapat diperdagangkan.

b) Harus diketahui jenisnya dan dapat ditentukan.

c) Barang-barang tersebut sudah ada atau akan ada dikemudian hari.

Mengenai obyek perjanjian, diperlukan beberapa syarat untuk menentukan sahnya suatu perikatan, yaitu : ${ }^{7}$

a) Obyeknya harus tertentu. Syarat ini hanya diperlukan bagi perikatan yang timbul dari perjanjian.

b) Obyeknya harus diperbolehkan, artinya tidak bertentangan dengan undang-undang, ketertiban umum atau kesusilaan.

c) Obyeknya dapat dinilai dengan uang. Hal ini dikarenakan suatu hubungan hukum yang ditimbulkan dari adanya perikatan berada dalam lapangan hukum harta kekayaan.

d) Obyeknya harus dimungkinkan. Orang tidak dapat mengikatkan diri kalau obyek tidak mungkin diberikan.

\section{Azas-Azas Perjanjian}

Pada pokoknya ada 4 azas penting yang terdapat dalam suatu perjanjian, sebagaimana dianut dalam Pasal 1320 KUHPerdata, yaitu :

a) Azas Kebebasan Berkontrak; sesuai dengan Pasal 1338 ayat (1) KUHPerdata bahwa setiap orang diperbolehkan membuat perjanjian apa saja asalkan dibuat secara sah dan selanjutnya mengikat para pihak yang membuatnya.

b) Azas Janji itu mengikat; bahwa orang terikat pada suatu perjanjian bukan karena ia menghendakinya namun karena ia telah memberikan janjinya.

c) Azas Konsensualisme; sebagaimana dapat disimpulkan dari Pasal 1320 KUHPerdata jo Pasal 1338 ayat (1) KUHPerdata, bahwa untuk melahirkan perjanjian adalah cukup dengan melahirkan kata sepakat mengenai hal-hal yang

7 Purwahid Patrick, Dasar-Dasar Hukum Perikatan, Mandar Maju, Bandung, 1994, hal. 4. 
pokok mengenai perjanjian tersebut dan perjanjian itu sudah mengikat pada saat terjadinya konsensus.

d) Azas Kepribadian, bahwa ruang lingkup berlakunya perjanjian hanyalah pada pihak-pihak yang membuat perjanjian saja. Pihak diluar perjanjian itu tidak dapat menuntut suatu hak berdasarkan perjanjian itu.

\section{Perjanjian Terapeutik}

\section{Perjanjian terapeutik sebagai salah satu bentuk perjanjian}

Perjanjian terapeutik adalah perjanjian antara dokter dengan pasien yang memberikan kewenangan kepada dokter untuk melakukan kegiatan memberikan pelayanan kesehatan kepada pasien berdasarkan keahlian dan keterampilan yang dimiliki oleh dokter tersebut. Dalam Mukadimah Kode Etik Kedokteran Indonesia yang dilampirkan dalam Keputusan Menteri Kesehatan RI Nomor 434 /Men.Kes /X / 1983 tentang Berlakunya Kode Etik Kedokteran Indonesia Bagi Para Dokter di Indonesia, mencantumkan tentang transaksi terapeutik sebagai berikut :

"Transaksi terapeutik adalah hubungan antara dokter dengan pasien dan penderita yang dilakukan dalam suasana saling percaya (konfidensial), serta senantiasa diliputi oleh segala emosi, harapan dan kekhawatiran makhluk insani”

Hubungan hukum dalam transaksi terapeutik timbullah hak dan kewajiban masing-masing pihak, baik bagi pihak pasien maupun pihak dokter. Suatu perjanjian dikatakan sah bila memenuhi persyaratan sebagaimana diatur dalam Pasal 1321 KUHPerdata yang menjelaskan :

"Tiada sepakat yang sah apabila sepakat itu diberikan karena kekhilafan atau diperolehnya dengan paksaan atau penipuan".

Sesuai pasal tersebut di atas dapat disimpulkan bahwa secara yuridis keabsahan suatu perjanjian ditentukan oleh kesepakatan para pihak yang mengikatkan dirinya, dengan tanpa adanya kekhilafan, paksaan ataupun penipuan. Sepakat ini merupakan persetujuan yang dilakukan oleh kedua belah pihak di mana kedua belah pihak mempunyai persesuaian kehendak yang dalam transaksi terapeutik sebagai pihak pasien setuju untuk diobati oleh dokter, dan dokterpun setuju untuk mengobati pasiennya. Agar kesepakatan ini sah menurut hukum, maka di dalam kesepakatan ini para pihak harus sadar (tidak ada kekhilafan) terhadap kesepakatan yang dibuat, tidak boleh ada paksaan 
dari salah satu pihak, dan tidak boleh ada penipuan didalamnya. Untuk itulah diperlukan adanya Informed Consent atau yang juga dikenal dengan istilah "Persetujuan Tindakan Medik".

Syarat adanya kecakapan untuk membuat perikatan/perjanjian, diatur dalam Pasal 1329 dan 1330 KUHPerdata sebagai berikut :

- Pasal 1329 : Setiap orang adalah cakap untuk membuat perikatan-perikatan, jika ia oleh undang-undang tidak dinyatakan tak cakap.

- Pasal 1330 : Tak cakap membuat suatu perjanjian adalah :

1. Orang-orang yang belum dewasa;

2. Mereka yang ditaruh di dalam pengampuan;

3. Orang-orang perempuan, dalam hal-hal yang ditetapkan oleh undang-undang dan pada umumnya semua orang kepada siapa undang-undang telah melarang membuat perjanjian-perjanjian tertentu.

Berdasarkan bunyi Pasal 1329 KUHPerdata di atas, maka secara yuridis yang dimaksud dengan kecakapan untuk membuat perikatan adalah kewenangan seseorang untuk mengikatkan diri, karena tidak dilarang oleh undang-undang. Pada transaksi terapeutik, pihak penerima pelayanan medik dapat meliputi berbagai macam golongan umur, dan berbagai jenis pasien, yang terdiri dari yang cakap bertindak maupun yang tidak cakap bertindak. Hal ini harus disadari oleh dokter sebagai salah satu pihak yang mengikatkan dirinya dalam transaksi terapeutik, agar tidak menimbulkan masalah dikemudian hari.

Pihak penerima pelayanan medik yang tidak cakap untuk bertindak (tidak boleh membuat kesepakatan, atau kesepakatan yang dibuat bisa dianggap tidak sah) antara lain : 8

1. Orang dewasa yang tidak cakap untuk bertindak (misalnya : orang gila, pemabuk, atau tidak sadar), maka diperlukan persetujuan dari pengampunya (yang boleh membuat perikatan dengan dokter adalah pengampunya).

2. Anak dibawah umur, diperlukan persetujuan dari walinya atau orangtuanya.

Kedewasaan menurut Peraturan Menteri Kesehatan Nomor 585/ Men.Kes/Per/IX/1989 Pasal 8 tentang persetujuan tindakan kedokteran ayat (2) adalah

\footnotetext{
${ }^{8}$ Anny Isfandyarie, Tanggung Jawab Hukum dan Sanksi Bagi Dokter, Prestasi Pustaka, Jakarta, 2006, hal. 61.
} 
telah berumur 21 tahun atau telah menikah. Jadi untuk seseorang yang berusia dibawah 21 tahun dan belum menikah, maka transaksi terapeutik harus ditandatangani oleh orangtuanya atau walinya yang merupakan pihak yang berhak memberikan persetujuan. Menurut Pasal 1320 KUHPerdata, obyek yang diperjanjikan terdiri dari mengenai 'suatu hal tertentu' dan harus 'suatu sebab yang halal atau diperbolehkan untuk diperjanjikan'. Dalam transaksi terapeutik, mengenai hal tertentu yang diperjanjikan atau sebagai obyek perjanjian adalah upaya penyembuhan terhadap penyakit yang tidak dilarang undang-undang.

Pada hukum perikatan dikenal adanya 2 macam perjanjian, yaitu $:^{9}$

1. Inspanningverbintenis, yaitu perjanjian upaya, artinya kedua belah pihak berjanji atau sepakat untuk berdaya upaya secara maksimal untuk mewujudkan apa yang diperjanjikan.

2. Resultaatverbintenis, yaitu suatu perjanjian yang akan memberikan resultaat atau hasil yang nyata sesuai dengan apa yang diperjanjikan.

Perjanjian terapeutik atau transaksi terapeutik termasuk dalam inspanningverbintenis atau perjanjian upaya, karena dokter tidak mungkin menjanjikan kesembuhan kepada pasien, yang dilakukan dokter adalah melakukan pelayanan kesehatan sebagai upaya untuk menyembuhkan pasien. Dalam melakukan upaya ini, dokter harus melakukan dengan penuh kesungguhan dengan mengerahkan seluruh kemampuan dan keterampilan yang dimilikinya dengan berpedoman kepada standar profesi.

Sementara itu, pasien sebagai pihak lainnya yang menerima pelayanan medis harus juga berdaya upaya maksimal untuk mewujudkan kesembuhan dirinya sebagai hal yang diperjanjikan. Tanpa bantuan pasien, maka upaya dokter tidak akan mencapai hasil yang diharapkan. Pasien yang tidak kooperatif merupakan bentuk contributory negligence yang tidak bisa dipertanggungjawabkan oleh dokter. Jika transaksi terapeutik telah memenuhi syarat sahnya perjanjian, maka semua kewajiban yang timbul mengikat bagi para pihak, baik pihak dokter ataupun pihak pasien.

Adapun kekhususan perjanjian terapeutik bila dibandingkan dengan perjanjian pada umumnya adalah sebagai berikut $:^{10}$

9 Ibid.,hal. 62. 
1. Subyek pada transaksi terapeutik terdiri dari dokter dan pasien. Dokter bertindak sebagai pemberi pelayanan medik professional yang pelayanannya didasarkan pada prinsip pemberian pertolongan. Sedangkan pasien sebagai penerima pelayanan medik yang membutuhkan pertolongan. Pihak dokter memiliki kualifikasi dan kewenangan tertentu sebagai tenaga professional di bidang medik yang berkompeten untuk memberikan pertolongan yang dibutuhkan pasien, sedangkan pihak pasien karena tidak mempunyai kualifikasi dan kewenangan sebagaimana yang dimiliki dokter berkewajiban membayar honorarium kepada dokter atas pertolongan yang telah diberikan dokter tersebut.

2. Obyek perjanjian berupa tindakan medik professional yang bercirikan pemberian pertolongan.

3. Tujuan perjanjian adalah pemeliharaan dan peningkatan kesehatan yang berorientasi kekeluargaan, mencakup kegiatan peningkatan kesehatan (promotif), pencegahan penyakit (preventif), penyembuhan penyakit (kuratif), dan pemulihan kesehatan (rehabilitatif), untuk mewujudkan derajat kesehatan yang optimal.

\section{Sifat perjanjian terapeutik}

Sifat atau ciri khas dari transaksi terapeutik sebagaimana disebutkan dalam Mukadimah Kode Etik Kedokteran Indonesia adalah :

1. Transaksi terapeutik khusus mengatur hubungan antara dokter dengan pasien.

2. Hubungan dalam transaksi terapeutik ini hendaknya dilakukan dalam suasana saling percaya (konfidensial) yang berarti pasien harus percaya kepada dokter yang melakukan terapi, demikian juga sebaliknya dokter juga harus mempercayai pasien. Oleh karena itu dalam rangka saling mejaga kepercayaan ini, dokter juga harus berupaya maksimal untuk kesembuhan pasien yang telah mempercayakan kesehatan kepadanya, dan pasienpun harus memberikan keterangan yang jelas tentang penyakitnya kepada dokter yang berupaya melakukan terapi atas dirinya serta mematuhi perintah dokter yang perlu untuk mencapai kesembuhan yang diharapkannya.

10 Veronica Komalawati, Peranan Informed Consent Dalam Transaksi Terapeutik, Citra Aditya Bakti, Bandung, 1999, hal. 145. 
4. Harapan ini juga dinyatakan sebagai 'senantiasa diliputi oleh segala emosi, harapan dan kekhawatiran makhluk insani'. Mengingat kondisi pasien yang sedang sakit, terutama pasien penyakit kronis atau pasien penyakit berat, maka kondisi pasien yang emosional, kekhawatiran terhadap kemungkinan sembuh atau tidak penyakitnya disertai dengan harapan ingin hidup lebih lama lagi, menimbulkan hubungan yang bersifat khusus yang membedakan transaksi terapeutik ini berbeda dengan transaksi lain pada umumnya.

\section{Azas-azas perjanjian terapeutik}

Oleh karena transaksi terapeutik merupakan hubungan hukum antara dokter dan pasien, maka dalam transaksi terapeutikpun berlaku beberapa azas hukum yang mendasari, yang menurut Veronica Komalawati disimpulkan sebagai berikut $:^{11}$

a. Azas Legalitas

Azas ini tersirat dalam Pasal 23 Undang-Undang Nomor 36 Tahun 2009 tentang Kesehatan yang menyatakan bahwa tenaga kesehatan bertugas menyelenggarakan atau melakukan kegiatan kesehatan sesuai dengan keahlian dan atau kewenangan tenaga kesehatan yang bersangkutan. Hal ini berarti bahwa pelayanan medik hanya dapat terselenggara apabila tenaga kesehatan yang bersangkutan telah memenuhi persyaratan dan perizinan yang diatur dalam peraturan perundang-undangan, antara lain telah memiliki Surat Tanda Registrasi dan Surat Izin Praktik.

b. Azas Keseimbangan

Menurut azas ini, penyelenggaraan pelayanan kesehatan harus diselenggarakan secara seimbang antara kepentingan individu dan masyarakat, antara fisik dan mental, antara materiil dan spiritual. Oleh karena itu diperlukan adanya keseimbangan antara tujuan dan sarana, antara sarana dan hasil serta antara manfaat dan resiko yang ditimbulkan dari upaya medis yang dilakukan.

c. Azas Tepat Waktu

Azas ini cukup penting karena keterlambatan dokter dalam menangani pasien dapat menimbulkan kerugian bagi pasien dan bahkan bias mengancam nyawa pasien itu sendiri.

d. Azas Itikad Baik

\footnotetext{
${ }^{11}$ Ibid., hal 126.
} 
Azas ini berpegang teguh pada prinsip etis berbuat baik yang perlu diterapkan dalam pelaksanaan kewajiban dokter terhadap pasien. Hal ini merupakan bentuk penghormatan terhadap pasien dan pelaksanaan praktik kedokteran yang selalu berpegang teguh kepada standar profesi.

e. Azas Kejujuran

Azas ini merupakan dasar dari terlaksananya penyampaian informasi yang benar, baik oleh pasien maupun dokter dalam berkomunikasi, Kejujuran dalam menyampaikan informasi akan sangat membantu dalam dalam kesembuhan pasien. Kebenaran informasi ini terkait erat dengan hak setiap manusia untuk mengetahui kebenaran.

f. Azas Kehati-hatian

Sebagai seorang professional di bidang medik, tindakan dokter harus didasarkan atas ketelitian dalam menjalankan fungsi dan tanggung jawabnya, karena kecerobohan dalam bertindak dapat berakibat terancamnya jiwa pasien.

g. Azas keterbukaan

Pelayanan medik yang berdayaguna dan berhasilguna hanya dapat tercapai apabila ada keterbukaan dan kerjasama yang baik antara dokter dan pasien dengan berlandaskan sikap saling percaya. Sikap ini dapat tumbuh jika terjalin komunikasi secara terbuka antara dokter dan pasien dimana pasien memperoleh penjelasan atau informasi dari dokter dalam komunikasi yang transparan ini.

\section{Persetujuan Tindakan Medis/ Informed Consent}

\section{Pengertian Persetujuan Tindakan Medis/ Informed Consent}

Secara harfiah Consent artinya persetujuan, atau lebih 'tajam' lagi, "izin”. Jadi Informed consent adalah persetujuan atau izin oleh pasien atau keluarga yang berhak kepada dokter untuk melakukan tindakan medis pada pasien, seperti pemeriksaan fisik dan pemeriksaan lain-lain untuk menegakkan diagnosis, memberi obat, melakukan suntikan, menolong bersalin, melakukan pembiusan, melakukan pembedahan, melakukan tindak-lanjut jika terjadi kesulitan, dsb. Selanjutnya kata Informed terkait dengan informasi atau penjelasan. Dapat disimpulkan bahwa Informed Consent adalah persetujuan atau izin oleh pasien (atau keluarga yang berhak) kepada dokter untuk melakukan tindakan medis atas dirinya, setelah kepadanya oleh dokter yang bersangkutan diberikan informasi atau penjelasan yang lengkap tentang tindakan itu. Mendapat penjelasan lengkap itu adalah salah satu hak pasien yang diakui oleh undang- 
undang sehingga dengan kata lain Informed consent adalah Persetujuan Setelah Penjelasan (PSP).

Sedangkan menurut Peraturan Menteri Kesehatan No 585/Men.Kes/Per/IX/1989 tentang Persetujuan Medik, Persetujuan Tindakan Medik adalah Persetujuan yang diberikan oleh pasien atau keluarganya atas dasar penjelasan mengenai tindakan medik yang akan dilakukan terhadap pasien tersebut. Menurut Peraturan Menteri Kesehatan No. 290/Menkes/Per/III/2008 tentang Persetujuan Tindakan Kedokteran, Persetujuan tindakan kedokteran adalah persetujuan yang diberikan oleh pasien atau keluarga terdekat setelah mendapat penjelasan secara lengkap mengenai tindakan kedokteran atau kedokteran gigi yang akan dilakukan terhadap pasien.

\section{Bentuk Informed Consent}

Ada 2 bentuk Persetujuan Tindakan Medis, yaitu : ${ }^{12}$

a. Implied Consent (dianggap diberikan)

Umumnya implied consent diberikan dalam keadaan normal, artinya dokter dapat menangkap persetujuan tindakan medis tersebut dari isyarat yang diberikan/dilakukan pasien. Demikian pula pada kasus emergency sedangkan dokter memerlukan tindakan segera sementara pasien dalam keadaan tidak bisa memberikan persetujuan dan keluarganya tidak ada ditempat, maka dokter dapat melakukan tindakan medik terbaik menurut dokter.

\section{b. Expressed Consent (dinyatakan)}

Dapat dinyatakan secara lisan maupun tertulis. Dalam tindakan medis yang bersifat invasive dan mengandung risiko, dokter sebaiknya mendapatkan persetujuan secara tertulis, atau yang secara umum dikenal di rumah sakit sebagai surat izin operasi.

\section{Fungsi dan Tujuan Informed Consent}

Fungsi dari Informed Consent adalah $:^{13}$

a. Promosi dari hak otonomi perorangan;

b. Proteksi dari pasien dan subyek;

c. Mencegah terjadinya penipuan atau paksaan;

d. Menimbulkan rangsangan kepada profesi medis untuk mengadakan introspeksi terhadap diri sendiri;

12 Amril Amri, Bunga Rampai Hukum Kesehatan, Widya Medika, Jakarta, 1997, hal. 31.

13 J. Guwandi, Informed Consent dan Informed Refusal, Penerbit Fakultas Kedokteran UI, 2003, hal 2. 
e. Promosi dari keputusan-keputusan rasional;

f. Keterlibatan masyarakat (dalam memajukan prinsip otonomi sebagai suatu nilai social dan mengadakan pengawasan dalam penyelidikan biomedik.

Informed Consent itu sendiri menurut jenis tindakan/ tujuannya dibagi tiga, yaitu : ${ }^{14}$

a. Yang bertujuan untuk penelitian (pasien diminta untuk menjadi subyek penelitian).

b. Yang bertujuan untuk mencari diagnosis.

c. Yang bertujuan untuk terapi.

Tujuan dari Informed Consent menurut J. Guwandi adalah ${ }^{15}$ :

a. Melindungi pasien terhadap segala tindakan medis yang dilakukan tanpa sepengetahuan pasien;

b. Memberikan perlindungan hukum terhadap akibat yang tidak terduga dan bersifat negatif, misalnya terhadap risk of treatment yang tak mungkin dihindarkan walaupun dokter sudah mengusahakan semaksimal mungkin dan bertindak dengan sangat hati-hati dan teliti.

Dalam keadaan gawat darurat Informed consent tetap merupakan hal yang paling penting walaupun prioritasnya diakui paling bawah. Prioritas yang paling utama adalah tindakan menyelamatkan nyawa. Walaupun tetap penting, namun Informed consent tidak boleh menjadi penghalang atau penghambat bagi pelaksanaan emergency care sebab dalam keadaan kritis dimana dokter berpacu dengan maut, ia tidak mempunyai cukup waktu untuk menjelaskan sampai pasien benar-benar menyadari kondisi dan kebutuhannya serta memberikan keputusannya. Dokter juga tidak mempunyai banyak waktu untuk menunggu kedatangan keluarga pasien. Kalaupun keluarga pasien telah hadir dan kemudian tidak menyetujui tindakan dokter, maka berdasarkan doctrine of necessity, dokter tetap harus melakukan tindakan medik. Hal ini dijabarkan dalam Peraturan Menteri Kesehatan Nomor 585/Men.kes/Per/IX/1989 Tentang Persetujuan Tindakan Medik, bahwa dalam keadaan emergency tidak diperlukan Informed consent. Sesuai dengan yang terdapat dalam Peraturan Menteri Kesehatan Nomor 290/Menkes/Per/III/2008 Tentang Persetujuan Tindakan Kedokteran, bahwa dalam

\footnotetext{
14 Ratna Suprapti Samil, Etika Kedokteran Indonesia, Yayasan Bina Pustaka Sarwono Prawirodihardjo, Jakarta, 2001, hal 45.

15 J. Guwandi, Rahasia Medis, Penerbit Fakultas Kedokteran UI, Jakarta, 2005, hal. 32.
} 
keadaan gawat darurat, untuk menyelamatkan jiwa pasien dan/atau mencegah kecacatan tidak diperlukan persetujuan tindakan kedokteran.

Ketiadaan informed consent dapat menyebabkan tindakan malpraktek dokter, khususnya bila terjadi kerugian atau intervensi terhadap tubuh pasiennya. Hukum yang umum diberbagai Negara menyatakan bahwa akibat dari ketiadaan informed consent setara dengan kelalaian/keteledoran. Akan tetapi, dalam beberapa hal, ketiadaan informed consent tersebut setara dengan perbuatan kesengajaan, sehingga derajat kesalahan dokter pelaku tindakan tersebut lebih tinggi. Tindakan malpraktek dokter yang dianggap setara dengan kesengajaan adalah sebagai berikut:

a. Pasien sebelumnya menyatakan tidak setuju terhadap tindakan dokter, tetapi dokter tetap melakukan tindakan tersebut.

b. Jika dokter dengan sengaja melakukan tindakan misleading tentang risiko dan akibat dari tindakan medis yang diambilnya.

c. Jika dokter dengan sengaja menyembunyikan resiko dan akibat dari tindakan medis yang diambilnya.

d. Informed consent diberikan terhadap prosedur medis yang berbeda secara substansial dengan yang dilakukan oleh dokter.

\section{KESIMPULAN}

Berdasarkan hasil pembahasan dapat disimpulkan sebagai berikut :

1. Implementasi persetujuan tindakan medis (informed consent) dalam pelayanan kesehatan. Persetujuan Tindakan Medis diatur dalam berbagai peraturan perundang-undangan yaitu UU No. 36 Tahun 2009 Tentang Kesehatan, UU No. 44 Tahun 2009 Tentang Rumah Sakit, UU No. 29 Tahun 2004 Tentang Praktik Kedokteran, Kitab Undang-undang Hukum Perdata (KUH Perdata), Permenkes No. 290/Menkes/Per/III/2008 Tentang Persetujuan Tindakan Kedokteran. Setiap tindakan yang akan dilakukan dalam pelaksanaan Persetujuan Tindakan Medis berpedoman pada peraturan perundang-undangan yang ada, berdasar formulir persetujuan tindakan medik yang baku.

2. Pelaksanaan persetujuan tindakan medik (informed consent) dalam pelayanan kesehatan. Keharusan adanya Informed Consent secara tertulis yang ditandatangani oleh pasien sebelum dilakukannya tindakan medik, karena erat kaitannya dengan 
pendokumentasiannya ke dalam catatan medik (Medical Record). Hal ini disebabkan, Rumah Sakit tempat dilakukannya tindakan medik tersebut, selain harus memenuhi standar pelayanan rumah sakit juga harus memenuhi standar pelayanan medik sesuai dengan yang ditentukan dalam keputusan Menteri Kesehatan No. 436/MENKES/SK/VI/1993 Tentang Berlakunya Standar Pelayanan di Rumah Sakit. Dengan demikian, Rumah Sakit turut bertanggung jawab apabila tidak dipenuhinya persyaratan Informed Consent. Apabila tindakan medik yang dilakukan tanpa adanya Informed Consent, maka dokter yang bersangkutan dapat dikenakan sanksi administratif berupa pencabutan surat izin praktik, Berarti, keharusan adanya Informed Consent secara tertulis dimaksudkan guna kelengkapan administrasi Rumah Sakit yang bersangkutan. Dengan demikian, penandatanganan Informed Consent secara tertulis yang dilakukan oleh pasien sebenarnya dimaksudkan sebagai penegasan atau pengukuhan dari persetujuan yang sudah diberikan setelah dokter memberikan penjelasan mengenai tindakan medik yang akan dilakukannya. Oleh karena itu, dengan ditandatanganinya Informed Consent secara tertulis tersebut, maka dapat diartikan bahwa pemberi tanda tangan bertanggung jawab dalam menyerahkan sebagian tanggung jawab pasien atas dirinya sendiri kepada dokter yang bersangkutan, beserta resiko yang mungkin akan dihadapinya.

3. Hambatan-hambatan dan solusi untuk mengatasinya dalam pelaksanaan persetujuan tindakan medik (informed consent) dalam pelayanan kesehatan. Hambatan yang ditemui dalam pelaksanaan persetujuan tindakan medik yaitu bahwa form persetujuan tindakan medik tidak ditandatangani oleh pasien sendiri padahal pasien dalam keadaan sadar. Selain itu informasi didapat oleh pasien dari perawat, juga dalam formulir persetujuan tindakan medik ada dokter yang tidak tanda tangan.

\section{SARAN}

1. Penerapan persetujuan tindakan medik (informed consent), antara dokter dengan pasien hendaknya saling menyadari bahwa masing-masing pihak punya hak dan kewajiban yang wajib dijunjung tinggi. Hal tersebut perlu untuk dipahami agar tidak timbul masalah yang dapat merugikan dikemudian hari dan dapat merugikan semua pihak. 
2. Antara pasien dan dokter hendaknya dapat lebih meningkatkan komunikasi, sebab dengan komunikasi yang baik maka penerapan persetujuan tindakan medik (informed consent) dapat berjalan dengan baik. Selain itu dengan adanya komunikasi yang baik akan lebih meminimalkan resiko terjadinya malpraktek di bidang medis.

3. Demi kepastian hukum di bidang medis, serta adanya jaminan hak dan kewajiban antara dokter dengan pasien, maka sebaiknya Permenkes No. 290/Menkes/Per/III/2008 yang mengatur tentang persetujuan tindakan medik (informed consent) dinaikkan tingkatnya menjadi Peraturan Pemerintah, serta ditambahkan tentang sanksi tegas bagi pelanggar ketentuan persetujuan tindakan medik (informed consent).

\section{DAFTAR PUSTAKA}

Amri, Amril. 1997. Bunga Rampai Hukum Kesehatan. Widya Medika, Jakarta

Dewi, Alexandra Indriyanti. 2008. Mafia Kesehatan. Pinus Book Publisher, Yogyakarta

Guwandi, J. 1994. Tanya Jawab Persetujuan Tindakan Medik (Informed Consent). Fakultas Kedokteran UI, Jakarta . 2003. Hukum Medik ( Medical Law). Penerbit FK UI, Jakarta 2003. Informed Consent dan Informed Refusal. Penerbit Fakultas

Kedokteran UI, Jakarta

Hartini, Inge M.C. 2004. Makalah Informed Consent dan Hukum Perdata. PDIH UNDIP, Semarang

Hermien Hadijati Koeswadji. 1998. Hukum Kedokteran (Studi Tentang Hubungan Hukum Dalam mana Dokter Sebagai Salah Satu Pihak), Citra Aditya Bakti, Bandung

Isfandyanie, Anny. 2005. Malpraktek dan Resiko Medik (Dalam Kajian Hukum Pidana). Prestasi Pustaka, Jakarta , 2006. Tanggung Jawab Hukum dan Sanksi bagi Dokter, Buku I.

Prestasi Pustaka, Jakarta 
Vol 1, No 1 (2018): Law \& Justice Journal, November 2018

2006. Tanggung Jawab Hukum dan Sanksi bagi Dokter, Buku II.

Prestasi Pustaka, Jakarta

Jamil, Ratna Suprapti. 2006. Etika Kedokteran Indonesia. Yayasan Bina Pustaka Saswano Prawirodirdjo, Jakarta

Komalawati, D. Veronika. 2002. Peranan Infomed Consent Dalam Transaksi

Terapeutik ( Persetujuan Dalam Hubungan Dokter dan Pasien) Suatu Tinjauan

Yuridis. PT. Citra Aditya Bakti, Bandung

Kuiters, H.M. 1991. Kematian yang Digandrungi (Eutanasia dan Hak Menentukan

Nasib Sendiri). Nova, Bandung

Leibo, Jef. 1986. Hukum dan Potensi Kedokteran Dalam Masyarakat Indonesia.

Hibsty, Jogjakarta

Maryanti, Ninik. 1988. Malpraktek Kedokteran (Dari Segi Hukum Pidana dan

Perdata). Bina Aksara, Jakarta

Miles, Matthew dan Huberman. 1992. Analisis Data Kualitatif. UI Press, Jakarta

Muhammad, Abdulkadir. 1982. Hukum Perikatan. Alumni, Bandung

Nasution, Bahdr Johan. 2005. Hukum Kesehatan Pertanggung Jawaban Dokter. PT

Bineka Cipta, Jakarta

Patrick, Purwahid . 1994. Dasar-Dasar Hukum Perikatan. Mandar Maju, Bandung

Praptianing, Sri. 2006. Kedudukan Hukum Perawat Dalam upaya Peayanan

Kesehatan di Rumah Sakit. PT. Raja Grafindo Persada, Jakarta

Satrio, J. 1992. Hukum Perjanjian. Citra Aditya Bakti, Bandung

Santoso, Aman, 2003, Metode Penelitian Hukum Normatif dan Sosiologis Dengan Analisa Kualitatif, Semarang : FH UNTAG

Soekamto, Soerjono dan Sri Mamudji. 2004. Penelitian Hukum Normatif : Suatu Tinjauan Singkat, Cetakan Kedelapan. PT. RajaGrafindo Persada, Jakarta

Soekamto, Soerjono. 1989. Aspek Hukum Kesehatan (Suatu Kumpulan Catatan). Ind-Hill-Co, Jakarta

1984. Pengantar Penelitian Hukum. UI Press, Jakarta

Soemitro, Ronny Hanitijo. 1988. Metode Penelitian Hukum dan Jurimetri. Ghalis Indonesia, Jakarta

Subekti, R. 1992. Hukum Perjanjian. Intermasa, Jakarta 
Vol 1, No 1 (2018): Law \& Justice Journal, November 2018

Tutik, Titik Triwulan dan Sita Febriana. 2010. Perlindungan Hukum bagi Pasien. Prestasi Pustaka Publisher, Jakarta PERATURAN PERUNDANG-UNDANGAN

UU No. 36 Tahun 2009 Tentang Kesehatan

UU No. 44 Tahun 2009 Tentang Rumah Sakit

UU No. 29 Tahun 2004 Tentang Praktik Kedokteran

Kitab Undang-undang Hukum Pidana (KUHP)

Kitab Undang-undang Hukum Acara Pidana (KUHAP)

Kitab Undang-undang Hukum Perdata (KUH Perdata)

Permenkes No. 290/Menkes/Per/III/2008 Tentang Persetujuan Tindakan Kedokteran 